\title{
Negligence Liability in Public Swimming Pool Operations: A Review of Case Law Involving Supervision
}

\author{
Daniel P. Connaughton, Ed. D. \\ Assistant Professor \\ Department of Exercise and Sport Sciences \\ University of Florida \\ P.O. Box 118205 \\ Gainesville, FL 32611-8205 \\ Email: danc@hhp.ufl.edu \\ Tel: (352) 392-0584, ext. 296 \\ Fax: (352) 392-5262 \\ John O. Spengler, J.D., Ph.D. \\ Assistant Professor \\ Department of Recreation, Parks and Tourism \\ University of Florida \\ P.O. Box 118208 \\ Gainesville, FL 32611-8208 \\ Email: spengler@hhp.ufl.edu \\ Tel: (352) 392-4042 ext. 314
}

\section{Introduction}

Swimming and its related activities are among the most popular leisure time activities in America today. According to the Sporting Goods Manufacturing Association (1999), recreational swimming was the most popular participation sport in the United States in 1998 with 99.4 million participants. Most of this activity takes place in swimming pools, as more people swim in pools than at beaches (Reagen \& Gabrielsen, 1990). Additionally, swimming pools have become a very popular setting for fitness and rehabilitation activities (Clement, 1997).

Unlike many participatory leisure activities, swimming is neither seasonal in nature nor scope. While the weather naturally limits outdoor swimming to the summer months in the northern states, swimming is often enjoyed on a year round basis in southern states. The use of pool covers, heaters, and solar panels has substantially extended the season in northern regions. Likewise, the construction of indoor pools, including residential, commercial, and public, along with the development of facilities at motels, hotels, clubs, and camps, has made swimming accessible and an all year activity in most areas.

Historically, the number of swimming pools in the United States has increased at a dramatic rate. For example, it was estimated that in 1945 there were 10,000 pools in the United States (Gabrielsen \& Olenn, 1982). The National Spa and Pool Institute (1994) estimated that in 1993 the number of in-ground swimming pools in the United States had climbed to 3.3 million. Public schools operate more than 25,000 swimming pools alone (Baley \& Matthews, 1989). 


\section{Statement of the Problem}

This tremendous growth in facilities and programs has brought additional opportunities and participants. Unfortunately, as a result of these growing numbers there have also been numerous injuries, deaths, and subsequent lawsuits. Stern (1978) stated that there had been a substantial increase in swimming pool-related litigation over the prior 25 years. Given the fact that the number of swimming pools and participants has increased dramatically since then, as well as the litigious nature of today's society, it can be inferred that this trend has continued.

Three possible incidents facing swimming pool operators that often lead to lawsuits are drownings, near drownings, and spinal cord injuries. Drowning accounts for approximately 5,000 deaths in the United States every year (American Red Cross, 1995). This figure includes intentional drownings such as murder and suicide. In 1997, unintentional drowning accounted for 4,051 of the 4,724 drowning deaths in the United States (Hoyert, Kochanek, \& Murphy, 1999). Although the United States drowning rate has dropped from 10.2 per 100,000 in 1900 to 1.8 per 100,000 in 1997 , drowning ranks second to the automobile as the cause of accidental deaths for people up to the age of 35 (Hoyert, et al., 1999). For public health purposes, drowning is defined as unintentional death from submersion asphyxia during or within 24 hours of the incident (Thanel, 1998).

Near drownings are also very common. For every drowning that occurs, it is estimated that four near drownings occur (American Red Cross, 1995). It has been shown that there are approximately four near drowning hospitalizations for every drowning that occurs and approximately four visits to a hospital emergency department for every hospitalization (Fields, 1992; Wintemute, 1990). Osinski (1990) reported that during the summer months approximately 50 near drownings occur per day. A near drowning is defined as survival for 24 hours or longer after submersion, whether the victim ultimately sur- vives or not (Thanel, 1998). Four to six minutes after a submersion incident, irreversible brain damage occurs and determines the immediate and long-term survival of a victim. Many of these victims are resuscitated but some are left with permanent physical and/or mental damage. Up to $20 \%$ of near-drowning victims suffer severe, permanent neurological disability (National Safe Kids, 1999). The quality of life for near drowning victims varies greatly. Some require costly long-term medical and nursing care. Typical medical costs for a near drowning victim can range from $\$ 75,000$ for initial emergency room treatment to $\$ 180,000$ a year for long-term health and medical care. The cost of a near drowning that results in brain damage can total more than $\$ 4.5$ million (National Safe Kids, 1999).

Another area of concern in swimming pool operation is the injuries and deaths that result from diving into water. However, it should be noted that no record of a fatality or catastrophic injury connected with a supervised practice session or competition in competitive diving exists (Gabriel, 1988). There has never been a documented serious accident in a real diving event (Clements as cited in Edelstein, 1999). Diving into shallow water, far removed from diving boards, causes the overwhelming majority of diving injuries. According to Gabriel (1992), 86\% of diving accidents occur in shallow water five feet deep or less while $13 \%$ occur in water that is five to nine feet deep.

It is estimated that 1,000 diving-related spinal cord injuries occur annually in the United States (American Red Cross, 1995). Paralyzing injuries from diving and sliding are much more common than is generally believed. The American Red Cross (1992) reported that the number of people who are paralyzed due to diving accidents exceeds the total produced by all other sports combined. While the exact number of spinal cord injuries that occur in pools as compared to other bodies of water is not known, some authorities estimate that as many as 30 to 
$40 \%$ of them may be pool related (Gabrielsen, 1987; DeVivo \& Sekar, 1997). This would account for approximately 300 to 400 swimming pool-related spinal cord injuries annually.

The catastrophic nature of spinal cord injuries, which often result in permanent disabilities, coupled with the astronomical cost of hospitalization and medical and attendant care, demands the attention of all swimming pool operators. Based on jury verdicts, preliminary information indicates the estimated annual costs of these injuries could total $\$ 1.4$ to $\$ 3.5$ billion (Gabrielsen \& Spivey, 1990). Due to rising medical and health care costs, it can be assumed that these figures have increased since 1990 and will continue to do so.

Drownings, near drownings, and spinal cord injuries are a substantial source of liability exposure for all aquatic organizations. These tragedies can be very costly, particularly for the defense, as awards and settlements in excess of one million dollars are not uncommon (Sobo, 1998). Besides the financial costs, they have destroyed careers, closed facilities, increased insurance costs, and created tremendous amounts of emotional stress for those involved. At the very least, they are poor for public relations and can cause a tremendous amount of professional embarrassment. Negative publicity about drownings and serious injuries could tarnish the organization's image and possibly decrease business income.

Aquatic sites can be analyzed from several viewpoints in regards to liability. This analysis can be made in reference to swimming pool design, construction of the facility, and maintenance, operation, or supervision of the site. Many swimming pool injury and wrongful death cases have involved situations relating to pool maintenance, management, and supervision. Negligent supervision appears to be among one of the fastest growing areas of litigation in aquatics.

There are many ways to reduce swimming pool injuries, drownings, and subsequent law- suits. The acquisition of knowledge and the understanding of safe procedures in aquatics are entirely in the control of administrators. Many swimming pool accidents are the result of a lack of attention to well known safety practices and guidelines. Careful investigation of pool injuries and drownings has shown that many could have been prevented. Because of the specialized nature of swimming pool facilities and the activities common to these areas, injuries and deaths from pool accidents tend to follow a pattern.

Although certain authority and specific responsibilities may be delegated to lifeguards, instructors, supervisors, and maintenance personnel, it is the administrator that is ultimately held responsible for the safe operation of the swimming pool. In an effort to reduce liability exposure, today's swimming pool administrators must be well informed of the legal aspects of the profession. Aquatic administrators must be $\operatorname{cog}$ nizant of court decisions and legal precedents handed down in legal cases involving aquatics. Specific legal duties and responsibilities expected of aquatic professionals can be obtained by an analysis of the many cases that have been decided by the courts in recent years. Previous court decisions should be reviewed not only when formulating safety policies, but also in an effort to avoid making mistakes similar to those that created liability for others.

\section{Case Law Examples}

Legal cases often set the precedent for standards in aquatics. The following case law examples focus on alleged negligent supervision for incidents that occurred in or around swimming pools open for public use. Each case is presented in narrative form and practical implications relevant to swimming pool supervision and standards are provided. The cases are for the purpose of illustration and address the following categories: failure to properly supervise, failure to eliminate horseplay, failure to provide a sufficient number of lifeguards, failure to provide lifeguards, failure to provide proper staff instruction/training, and failure to provide locker room 
supervision.

\section{Failure to Properly Supervise}

Aquatic operators are expected to provide adequate supervision. The need for close and constant supervision and control over the entire swimming pool facility is well illustrated by the decisions of several courts holding operators liable for injuries resulting from poorly supervised situations. Although lifeguards may not be required at many swimming pools, most would agree that the presence of a sufficient number of conscientious and qualified lifeguards contributes greatly to the safety of any aquatic program. Additionally, the case law has established that a lifeguard must exercise a high degree of care in the performance of his or her job. In addition to being required to warn about or remedy dangerous conditions on the premises, swimming pool operators are under a duty to properly supervise and rescue patrons. The operator is ordinarily required to supervise activities so that patrons are safeguarded from natural hazards and from the action and conduct of others.

In the case of Barnett $v$. Zion Park District (1996), a 10-year-old boy was enjoying the swimming pool operated by the Zion Park district. He had climbed the ladder to a diving board and had walked out to the end when he slipped and hit his head on the top of the diving board. He then fell unconscious into the pool and sunk to the bottom of the deep end. Several other swimmers saw this and went to the lifeguards for help. One lifeguard, when told of the situation, replied to the plea for help with indifference. The lifeguard responded that the child had been with a group that had been causing trouble, said that the boy was alright and they were only playing, then turned away. Another lifeguard was approached by a different swimmer who was met with equal indifference. The swimmer then ran to the lifeguard shack where he summoned help. The boy was pulled from the water but not before he had drowned. The boy's mother sued the park district for the negligence of the lifeguard staff. She claimed that the lifeguards exhibited willful and wanton misconduct in the way they handled the situation. The Illinois Supreme Court affirmed the Appellate Court's ruling in favor of the defendant. The court held that even had the defendant exhibited willful and wanton misconduct, the governmental immunity statute protected the Park District from liability.

The case of Cassio v. Creighton University (1989) is a tragic reminder of the duty and necessity to provide constant supervision to every patron in a swimming pool. Cassio, a highly certified and experienced scuba diver, was in the deep end of the pool when he experienced problems. At the time of the incident, the lifeguard was not in her elevated guard chair supervising the pool, but on the deck talking to her supervisor. Furthermore, the lifeguard was unable to retrieve Cassio from the bottom of the pool because he was too heavy. She came back up after an attempt and claimed she was hurt. A man who had been lifting weights near the pool, dove in and got him out of the pool with the supervisor's assistance. Efforts to revive Cassio were unsuccessful.

At the time of the incident, Omaha ordinances required that two lifeguards be present at pools of Creighton's size and that a pool of Creighton's classification was to be under the immediate supervision of a certified operator. Evidence was introduced which indicated Creighton's violation of the ordinances by having only one lifeguard on duty and no certified operator. The court awarded the plaintiff's estate $\$ 118,940$ in damages. The trial court's decision was affirmed on appeal.

In Williams v. United States (1987), the plaintiff brought a wrongful death claim against the United States after his 16-year-old son drowned in a swimming pool located at an Air Force base. The court found the lifeguards were not attentive to the activities in the diving area of the pool. Evidence indicated that one lifeguard was in her position, but was engaged in conversation with a patron instead of giving her attention to the patrons entering the deep end of the pool from 
the diving boards. As a result, the court found that the lifeguards lost observation of Williams for an unreasonable period of time and were therefore negligent. The court concluded that had the recovery been prompt, Williams could have been resuscitated without brain damage so severe that it ultimately caused his death. The lifeguard's failure to observe the decedent for several minutes was the proximate cause of his brain damage and resulting death. Her memory of the incident clearly indicated that she was inattentive to her duties. The court also noted that the lifeguard was clearly inexperienced and was given responsibility without any supervision or adequate training and preparation for the emergency use of cardiopulmonary resuscitation. The court also held that a signed release did not relieve the government of liability. The federal district court entered judgment for the plaintiff. Damages were awarded to cover medical and funeral expenses as well as $\$ 150,000$ for mental grief.

Another case in which the inattentiveness of the lifeguards was at issue was Robinson v. City of Decatur (1985). Action was brought against the city to recover damages for injuries a sixyear-old sustained in her near drowning in a municipal swimming pool. The child was found in seven feet of water at the bottom of the pool. Due to being submerged for approximately three minutes, she suffered brain damage and a permanent loss of mental capacity. It was alleged that the lifeguards on duty the day of the accident were inadequately trained in their duties and were inattentive to their responsibilities.

The court noted that it had been held uniformly in the state of Georgia that the operation of public recreational swimming facilities, primarily for public benefit rather than for revenue generation, is a governmental function, so the city is shielded from negligence claims by the doctrine of governmental immunity. The city further noted that the purchase of general liability insurance does not waive sovereign immunity. The trial court's grant for summary judgment in favor of the defendant municipality was affirmed.

In Honeycutt v. City of Monroe (1971), the plaintiff alleged that failure of the pool lifeguards to quickly respond to an appeal for help from the decedent's companions was the cause of death. On the day of the accident, the deep end of the pool was roped off because it was murky from an excess of "Dakelite," a pool chemical, and patrons were warned not to enter that area. The water in the shallow end was clear. Evidently, someone yelled to the three lifeguards on duty that a boy was going under the rope towards the deep end. Since the water was too cloudy for them to see, all three dove in and checked the bottom, but found no one. They moved the rope back towards the shallow end for better observation. Another two or three alarms were given that someone was in the deep end and each time the guards checked to no avail. Someone, possibly the locker room attendant, reported that the plaintiff was missing, whereupon, via the PA system, the pool was cleared. When he was still missing, a further check found him on the bottom of the deep end. Resuscitation efforts failed.

The court stated that, "a municipality, in the operation of a public swimming pool, is not the insurer of the safety of those making use of such facility. However, the jurisprudence has established that a lifeguard at a public pool must exercise a high degree of care." The court held that considering the murky water of the deep end and the crowded conditions of the shallow end, the evidence supported the conclusion of the trial judge that the response of the lifeguards to the first alarm was less than diligent. The court further agreed with expert medical testimony suggesting that had the decedent been found immediately after the guards were notified that he was drowning, resuscitation efforts would, in all likelihood, have been successful. The court stated, "We recognize the duty of care a lifeguard owes to patrons at a public swimming pool to be more than the standard of care required of ordinary persons. A lifeguard, by training and experience, is expected to be prepared at a moment's notice 
to rush to the rescue of those in danger of drowning. His is not an obligation which can be discharged by inattention to the activity in the pool and a lack of awareness of the serious nature of the responsibility imposed upon the position." The court concluded that, "the failure of the lifeguards to observe Stanley thrashing about in the deep end and to make diligent efforts to rescue him constituted negligence which was a proximate cause of the accident." The court affirmed the judgment for the plaintiff.

A judgment that an apartment complex was liable for the drowning of a 14-year-old tenant was affirmed in $S \& C$ Co.v. Horne (1977). The court ruled that the lifeguard's failure to observe the distress of the victim as soon as he should have was the proximate cause of the drowning. Evidence indicated that others observed the victim in the pool splashing shortly before the accident. The lifeguard had been sitting on the pool deck eating ice cream with a group of friends. A patron shouted for the rescue squad after she and her daughter pulled the decedent up from the bottom of the pool. The lifeguard attempted resuscitation, but there was no equipment at the pool. He then gave a bystander a coin and told her to call the rescue squad. All attempts to resuscitate were unsuccessful.

The lifeguard blamed the failure to see the body on the glare from the sun. However, a photograph showed that the portable guard chair was not properly located in relation to the sun's glare, as well as not being at the water's edge. Additionally, the water was cloudy and one could not see the bottom. There had been filter problems earlier that season. The court noted that even if the decedent's splashing had no ominous significance and that he was under the surface of the water when he first experienced difficulty, it is reasonable to infer that he struggled to save himself and that a qualified lifeguard would have recognized his struggle. Whatever signs of distress there may have been, the lifeguard did not see them. The plaintiff argued that if the guard had positioned the chair away from the setting sun, placed it at the water's edge, and remained seated in the chair, he would have been able to observe any signs of distress in the water beneath him. The court stated that for one or more reasons, the lifeguard did not see what a qualified lifeguard reasonably should have seen. The court also added that due to the cloudy water, improper position of the lifeguard chair, and the lifeguard's preoccupation with activities which distracted him from the performance of his duties there was a reasonable probability that the drowning would not have occurred.

A swimming pool operator is not an insurer of his or her patron's safety. However, the need for close and constant supervision is well illustrated by the decisions of several courts that held operators liable for injuries or drownings resulting from poorly supervised situations as seen in the Cassio and Williams cases. Among the cases surveyed, swimming pool operators have been held liable for a drowning or injury that occurred as a result of the lifeguard's inattention, failure to enact a prompt rescue, or for any other negligence in the performance of his or her duties. If a swimming pool operator provides a lifeguard, the lifeguard must not only observe swimmers in order to detect any signs of distress, and be prepared to rescue those who might be in danger, but must also act properly and promptly.

\section{Failure to Eliminate Horseplay}

In addition to suits alleging improper supervision that led to drownings, near-drownings, or spinal cord injuries, several courts have held that the failure of lifeguards who were on duty to prohibit or closely supervise boisterous conduct, which resulted in injuries, rendered the operators of the facility liable. An aquatic operator may be held liable in not eliminating horseplay if that horseplay could have been prevented by the lifeguards but was not, and it resulted in a patron being injured.

For example, in Manganello v. Permastone, Inc. (1977), the plaintiff was injured by other swimmers doing back flips from each other's shoulders. The lifeguards on duty did nothing to 
stop or control what the plaintiff described as "horseplay." Testimony indicated that it was permitted to continue for at least 20 minutes before the plaintiff was injured by one of the young participants who landed on the back of the plaintiff's head and neck forcing him under the water. The court permitted an expert witness who testified that it was not an acceptable aquatic practice to allow young men to get on one another's shoulders and do back flips into the water. The court said that the supervision required by the proprietor of the swimming facility to which the public is invited is not merely for the purpose of warning those who are in imminent danger or rescuing those who have been injured, but includes the duty to guard the swimming facility and the surrounding area for potentially dangerous activities. The court further stated that boisterous conduct is not dangerous per se, but that injury is foreseeable when that conduct is permitted to continue without restriction, and that if rough or boisterous play is to be permitted, it should be confined to a restricted area, or at a minimum closely guarded.

Another horseplay related case is Stillwell $v$. City of Louisville (1970). The seventeen-yearold plaintiff brought action for personal injuries she suffered while she was a patron at a swimming pool operated by the city. She was severely injured when, on three separate occasions, another patron came up between her legs and flipped her over his head. The chief lifeguard at the pool testified that under the printed safety standards for the operation of the swimming pools adopted by the City, horseplay in swimming pools was to be prevented and controlled by lifeguards. Evidence indicated that the standards required three lifeguards, but only one was provided on the day of the accident. There was also evidence introduced that in the other pools operated by the City, "flipping" was not permitted and the rule against it was regularly enforced. Testimony by the chief lifeguard of the pool where the plaintiff was injured indicated that he considered "flipping" was not a dangerous activ- ity, but rather it was just "normal fun."

The court stated that "flipping" might be considered as boisterous conduct with injury as a foreseeable consequence. The court also noted that the pool's regulations and safety standards prohibited this type of conduct and that a jury could find that the City did not use ordinary care under the circumstances to discover and prevent the conduct which caused the plaintiff's injuries. The court also rejected the contention that the presence of a lifeguard may not have prevented the harm, saying that a jury could infer to the contrary. The standards themselves and their strict enforcement by the City at other pools constituted evidence that the very harm designed to be prevented was the harm that in fact occurred. Additionally, the court held that the plaintiff was not contributorily negligent in failing to report the incidents to a lifeguard. Ordinarily, a patron of a public amusement place does not assume the risk of injury from the negligence of third persons, which could have been prevented by the proprietor.

In Shields v. Watervliet (1973), action was brought by a mother of an infant for injuries sustained when, while attending city's swimming pool, a boy picked her up against her will and jumped into the pool. The injury consisted of substantial damage to her two front incisor teeth, which had to be extracted as a result of the accident. The defendant did not dispute that it had a duty to provide reasonable supervision. The court held that the record presented issues of fact for the jury as to whether the supervisors at the pool were negligent and whether that negligence was the proximate cause of the injury. Thus, the jury was warranted in rendering a decision for the plaintiff. However, the court concluded that the damages awarded to the plaintiff were inadequate while damages awarded to the plaintiff's mother were excessive. The court reversed judgment for both plaintiffs.

Defendants have been held not liable in several other cases when the boisterous conduct consisted merely of a single isolated incident, when 
the injured patron was a participant of the boisterous conduct, or when the injured patron voluntarily entered the facility knowing that the boisterous conduct was in progress. The following cases illustrate these situations.

In Smith v. Village of Pine River (1975), a municipality was held not liable for the severe injuries sustained by a 14-year-old patron who, while standing on a diving platform at a municipal bathing beach, was pushed from behind by another patron and fell over eight-feet to the cement. Because the injured plaintiff held on to the railing after he was pushed, he was thrown backwards below the floor of the platform and therefore fell on to the cement base of the platform, rather than into the water. The plaintiff alleged that the municipality was negligent in failing to supervise the children adequately to prevent horseplay and in failing to permit only one person on the platform at a time. The court stated that to charge a lifeguard or other supervisor with the responsibility of seeing all incidents involving horseplay by 40 to 50 children at even a small beach and to hold her negligent for failure to do so, went far beyond the concept of reasonable or due care. The court said to do so would make the municipality an insurer of all children injured during the course of youthful horseplay. Judgment was affirmed for the defendants. A municipality cannot anticipate all possible combinations of circumstances that might lead to injury from the use of their facilities.

A case in which the injured patron was a voluntary participant in the boisterous conduct is found in Dartez v. Gadbois (1976). Action was brought against a swimming pool owner based on a theory that its negligent supervision of the swimming pool was the proximate cause of injuries sustained by a young man when, as he was swimming, was struck in the eye by a green berry thrown by a friend. The court affirmed a judgment for the defendants, finding the patron contributorily negligent. Noting that there was evidence that the plaintiff threw some berries back at his friend, the court stated that the jury might reasonably have believed that the two boys voluntarily engaged in an activity and that a person of ordinary prudence in the exercise of ordinary care would not have engaged in such activity under the same or similar circumstances. The court further stated that the jury might have reasonably believed that the plaintiff's voluntary participation in the activity was one of the reasons his friend continued to throw the berries and that had the plaintiff not joined in the throwing, the friend would not have thrown the final berry which caused the injury. Furthermore, there was evidence that a lifeguard warned both patrons not to throw berries and had begun to dismount his elevated stand for the purpose of preventing further throwing of berries. The court concluded that the evidence supported a finding that after the lifeguards discovered that the plaintiff was in a position of danger and would probably not extricate himself, the lifeguard did not fail to use the means available to him with ordinary care to avoid the occurrence.

Another case in which the injured patron voluntarily entered into boisterous conduct is found in Jeffords v. Atlanta Presbytery, Inc. (1976). A volunteer children's camp director brought action against a church corporation that owned and operated the camp to recover for an eye injury sustained during a water basketball game at the camp swimming pool. The plaintiff who sustained a detached retina alleged that the church was negligent in its failure to properly train and instruct the counselors and in providing adequate qualified personnel to supervise the swimming activities. The plaintiff testified that, although there was a lifeguard on duty the day of the accident, he noticed that the water basketball game was "rather rough" and cautioned the participants several times that "someone was going to get hurt," but that they paid no attention to his warnings and continued to play. Nevertheless, the director voluntarily got into the pool and joined a "rough game in progress," and while reaching for the ball was struck in the eye by the fingers of one of the participants. 
The court noted that the basis of the proprietor's liability was his superior knowledge and if his invitee knows of the condition or hazard there is no duty on the part of the proprietor to warn him. Therefore, there was no liability for the resulting injury because the invitee had as much knowledge as the proprietor did and then by voluntarily acting, in view of his knowledge, assumed the risks and dangers inherent to the known condition. The court concluded that the testimony of the plaintiff showed that this was not an instance where the owner knew of a hazard and the plaintiff did not. Instead, the court said that the plaintiff had as much knowledge as the proprietor of the rough game in progress when he voluntarily entered the game, and therefore assumed the risks and dangers inherent in the condition. The judgment in favor of the defendant was affirmed.

Swimming pool operators are expected to formulate and consistently enforce safety rules. Certain rules and regulations are necessary to promote a safe environment. Many pools have rules designed to limit or prevent horseplay. As seen in Mangello, operators have been held liable in cases when lifeguards failed to prohibit or closely supervise boisterous conduct, which resulted in a patron being injured. However, contrary results have been reached when the injured patron was a participant to the boisterous conduct as seen in Dartez, or when the injured patron voluntarily entered into the facility knowing that the boisterous conduct was in progress as seen in Jeffords.

\section{Failure to Provide a Sufficient Number of Lifeguards}

A swimming pool operator's primary concern must be for the safety of their patrons. There must be constant and uninterrupted supervision of all patrons. The number of lifeguards on duty must be adequate for the size of the pool, the number and type of users, the activities being conducted, and the environmental conditions which may limit a lifeguard's ability to adequately perform his or her job. The number of guards required and the degree of supervision is proportional to the danger that is known or can reasonably be expected. Patrons participating in highrisk activities, those composed of weak or nonswimmers, young children, and those mentally and/or physically challenged, must be kept under particularly close supervision.

The inadequacy of the number of lifeguards on duty during the time of the incident is frequently raised as an issue. What is adequate is situational, depending on the swimming ability of the people at the facility and the facility's conditions, including size, water clarity and crowdedness. However, many states regulate bather load, or maximum capacity, and lifeguard to patron ratios. These regulations vary greatly among states as they often use different methods for determining maximum pool capacity and/or how many lifeguards must be on duty. Some states provide a sliding scale or range for determining supervisory ratios. For example, California codes require the number of guards to be "adequate enough to maintain continuous sur" veillance." In Washington, pool operators must "ensure a response time of less than 30 seconds based on, but not limited to: pool depth, bather load, training procedures, emergency procedures, and lifeguard rotations." In Oregon, codes allow for the use of a "10/20" guest protection standard. The state defines the system as one "which enables and requires a lifeguard to consistently and completely scan his/her assigned guest protection zone within 10 seconds and, should the guest need assistance, reach the guest and begin managing an incident within 20 seconds" (Johnston \& Bruya, 1999). For risk management purposes, state requirements should be considered the minimum. The capacity and actual usage of a swimming pool facility may indicate a need for more lifeguards than the number required by law (Holford, 1987).

In Phillips v. Southeast 4-H Educational Center, Inc., et al (1999), a 32-year-old man drowned while swimming laps at a pool operated by the defendant. On the day of the incident, two 
certified lifeguards were on duty. One of the lifeguards was the pool's senior lifeguard and manager. The patron was swimming laps both above and below the water. After swimming several laps underwater, he stood up in the shallow end and then sat underwater. The lifeguard noticed bubbles coming to the surface. When the bubbles stopped, the guard was in the water within "moments." The swimmer was pulled from the water and immediately given CPR. The other guard called for emergency response personnel. The rescue squad arrived in ten minutes, during which time CPR was administered continuously. The swimmer was pronounced dead on arrival at the hospital. The wife of the deceased sued the defendant for negligence. Central to her case was the theory that the lifeguards were negligent in not recognizing that her husband was unconscious sooner and, if they had, he could have been saved. In particular, she claimed that the lifeguards breached the "10/20-second rule." It was claimed the breach occurred since the lifeguard waited a minute before effecting a rescue after noticing the bubbles had stopped. The court did not agree and held that the plaintiff did not demonstrate proof of causation. Judgment was for the defendant.

In the case of Johnson v. City of Darlington (1991), eight-year-old Jeremy Johnson was spending the afternoon swimming at the outdoor city swimming pool. Three lifeguards were on duty that day but none were at their stations. One was talking with some friends in the far corner of the complex, the second was talking with friends outside the fence surrounding the pool, while the third was standing at the edge of the pool on the far end. While the lifeguards were away from their posts, Jeremy slipped beneath the surface and drowned. Jeremy's parents sued the city claiming that the lifeguards were negligent in failing to properly supervise the pool area. His parents lost the case. They argued that health code regulations, which governed safety at public pools, were violated. The regulations provided the requirements for the number of lifeguards who must be at their posts at any given time for a pool of a given size. The court, though deciding the case in favor of the defendant on other grounds, gave consideration to the administrative regulations as setting the standard of care for this case.

A lifeguard's primary responsibility is patron safety. Lifeguards should not be given additional duties that take them away from this all-important duty. They must provide diligent, careful supervision at all times. Lifeguards must leave their areas of responsibility unsupervised in emergency situations only. While it is reasonable to expect that these situations may occasionally occur, a facility must have a plan that provides appropriate back-up supervision and support.

In Corda v. Brook Valley Enterprises Inc. (1983), the only lifeguard on duty was taking down umbrellas and making other preparations for an approaching storm when a swimmer drowned. The lifeguard testified that he was away from his post for less than two-and-onehalf minutes. The court held that the lifeguard owed the plaintiff a duty to exercise the care that a reasonably prudent person who was serving as a lifeguard at the club at the time would have exercised. Further, the court held that there was enough evidence presented for the jury to decide that the lifeguard had not acted in a manner consistent with that duty. Additionally, the court held that it was a question for the jury to decide whether the defendant acted reasonably in not providing two lifeguards when the responsibilities of the position included maintenance. A new trial was granted on appeal.

In Mullery v. Ro-Mill Construction Corp. (1980), a wrongful death action was brought against a private health club. After swimming in the defendant's pool for a period of time, the decedent exited the water, suddenly mounted a lifeguard tower and dove into the shallow portion of the pool, fracturing his spine. At the time of the accident, the lifeguard was checking patrons in at the pool's entrance and was not in his assigned tower. The plaintiff alleged that the 
employees of the health club knew or should have known of the decedent's condition, and that the defendants were negligent in not prohibiting the deceased from entering the swimming pool. The court noted that there was evidence that the deceased was to some extent intoxicated. The court concluded that the totality of the evidence disclosed no basis for the conclusion that the defendants knew or should have known that the deceased was so intoxicated that he was unable to take care of himself and that his judgment was so impaired that he was likely to undertake such a dangerous action. The judgment in favor of the plaintiff was reversed and the complaint was dismissed.

Many swimming pool operators include some type of maintenance or other additional responsibilities in their lifeguard's job descriptions. However, no duty should interfere with a lifeguard's primary responsibility of patron safety. The Corda and Mullery cases are excellent examples that alternative provisions must be made if lifeguards are involved in any other duty besides providing constant supervision of patrons. Alternatives could include, having more than one lifeguard on duty, requiring all patrons to exit the water before the lifeguard leaves his or her station, employing additional staff to perform the additional duties, or if possible, requiring the lifeguard to perform the duties after the facility is closed and secured.

The need for close and constant supervision is well illustrated by the decisions of several courts holding swimming pool operators liable for drownings or injuries resulting from poorly supervised situations. When a swimming pool provides lifeguard services, it has a duty to perform those services with reasonable care. Failure to do so constitutes possible negligence liability.

\section{Failure to Provide a Lifeguard}

Although the furnishing of lifeguards is not legally mandated at many swimming pool facilities, the presence of a sufficient number of qualified and conscientious lifeguards contributes greatly to the safety of any swimming facility.
The following cases resulted from situations where lifeguards were not employed.

In Turner v. Parish of Jefferson, Houma Motels, et al (1998), a twelve-year-old girl drowned in a Holiday Inn swimming pool. There were no lifeguards at the pool. The young girl was with her basketball team who was participating in a regional tournament. Her parents were not with her on this particular trip. She was under the supervision of volunteer coaches. After completing the tournament game on Saturday, the team had dinner and arrived back at the hotel at about 9:00 P.M. The pool closed at 10:00 P.M. Upon their return to the hotel, the group went to the Holidome pool for a swim. Testimony revealed there were approximately 30 to 50 people in the pool. The pool was crowded with children swimming and playing. It was very loud in the pool area. A swimmer testified that he saw the girl playing tap ball with a group of children in water that was a little below her shoulders. He also saw her go into the six-foot depth area on several occasions to retrieve the ball. She eventually left the game to swim elsewhere. The other swimmer stayed to play the game of tap ball. On one occasion, the ball was knocked into the sixfoot deep area. The swimmer retrieved the ball and walked back. He stepped on something that he thought was a toy. The water was cloudy and he could not see the bottom. A few seconds later he had to retrieve the ball again and decided to see what he had stepped on earlier. It was the girl on the bottom of the pool. He dove under and brought her to the surface where she was given CPR. The coach ran to find someone to call 911. Efforts to save the girl were unsuccessful. Evidence revealed there were no hotel employees or security personnel monitoring activities around the pool at the time of the drowning. The hotel manager on duty was also not in the area.

The girl's parents brought a wrongful death suit against the hotel and other named parties. Part of their claim was that the hotel was negligent in failing to provide a lifeguard. The court held that the hotel breached its duty to maintain 
the premises in a reasonably safe and suitable condition. A central component of this duty was to have supervision given the number of children known to be using the pool. The hotel knew that there would be many children staying at the hotel that weekend for the basketball tournament. They also had reason to believe, from prior experience, that the pool would be crowded with children. Even with this knowledge, the hotel failed to employ a temporary lifeguard or staff someone with water safety training to monitor the pool area. Additionally, with the knowledge of potential crowding in and around the pool area, the hotel neither possessed nor posted a requirement relative to pool capacity. Further, there was not a safety rope at the deep end, depth markers at the deep end were not displayed, and the water was cloudy. Given these facts and circumstances, the court found the defendant negligent.

In Ely v. Northumberland General Insurance Company (1979), a health club patron sued for damages he sustained in a near drowning accident in the club's pool. After working out in the exercise room, the plaintiff used the steam room, sauna, and whirlpool bath, then took a cold shower and went to the swimming pool. He started swimming and then lost consciousness. He was found on the bottom of the pool by a patron, who retrieved him from the pool and administered first aid. As one allegation, the plaintiff charged the club with failure to provide a lifeguard and sufficient supervisory personnel. The court held that the health club owed a duty to exercise due diligence and care to see that none of the patrons of its pool were injured through its fault. The trial court's decision was reversed and the case was remanded for determination of negligence.

In Ald v. Cunningham (1970), the court reversed a judgment that the motel owners were not liable for the death of a paying guest who drowned in the motel pool that was not supervised by a lifeguard and was not furnished with lifesaving equipment. The court concluded that the trial judge committed a reversible error by refusing to allow testimony by an aquatic supervisor for the Detroit Department of Parks and Recreation as to the standards of water safety within the state of Michigan and the United States as set forth by the Young Men's Christian Association (YMCA) and the American Red Cross (ARC). The court further stated that the motel owners had a duty to exercise reasonable care for their guests, and that the issue of whether the owners' failure to provide a lifeguard or rescue equipment constituted a breach of that duty was question for the jury to decide.

However, a judgment was affirmed for the defendants in Andrews v. Taylor (1977) when it was determined that the decedent was a licensee. Wrongful death action was brought following a tenant's drowning in the swimming pool at the defendant's apartment complex. On the day of the accident, the decedent dove off the diving board and landed near the lifeline, which ran across the middle of the pool. The depth of the water at this point was five feet. He did not surface for about one minute and was finally pulled from the water by several men. He was not breathing and had a bruise on his forehead. Attempts to revive him were unsuccessful.

A sign was posted at the entrance to the pool that stated, "No lifeguard on duty. Swim at you own risk." Evidence indicated that the pool was not in violation of the local board of health's regulations governing swimming pools. The court ruled that the defendant was a licensee, and that an owner owes only the duty to refrain from injuring him willfully or through wanton negligence, and from doing any act, which increases the hazard to the licensee while he is on the premises. The court held that no facts were presented to show or justify the inference that the defendant was willfully or wantonly negligent in the operation or maintenance of the pool. The failure to provide lifeguards and rescue equipment did not amount to negligence in light of the absence of any regulation requiring them. Furthermore, the plaintiff failed to show that the availability of lifeguards or rescue equipment 
would have prevented the decedent's death. The trial court's judgment for the defendants was affirmed.

Astute swimming pool operators are aware of and comply with their state's bather load restrictions and supervisory ratios. Failure to do so may result in liability as seen in the Turner case. Signage indicating maximum pool capacity and/or the lack of lifeguards should be posted in highly visible areas where they are unlikely to be missed. Signage should also meet the expectations of each facility's legal counsel.

Every staff member at a swimming pool facility has the shared responsibility of patron safety. Swimming pool operators should ensure that the entire staff is alert to and following the safety requirements of the facility. This is especially important in those facilities that do not employ lifeguards. For example, front desk, maintenance, and security personnel can enforce certain pool safety rules, ensure that bather limits are not violated, and activate emergency action plans when necessary.

\section{Failure to Provide Proper Staff Instruction/Training}

Swimming pool operators are expected to provide proper staff instruction and training. Typically, lifeguards are only generally trained and, therefore, must be provided with specific training that is directly related to their facility, environment, and equipment available. Regular in-service training not only provides for new learning opportunities but also helps to prevent important rescue and first aid skills from deteriorating.

Swimming pool operators must not only try to prevent injuries, but they must also plan for them. Written emergency action plans must be specifically designed for each facility. These plans must be regularly practiced and modified when necessary. Several cases illustrate this important duty.

In Cater, et al v. City of Cleveland (1998), a twelve-year-old boy died from complications incurred as the result of a near drowning at a municipal indoor swimming pool. On the day of the incident, there were four Red Cross certified lifeguards on duty. The boy was at the pool during open swim which lasted from 1:00 to $4: 30$ P.M. One of the lifeguards patrolled the deck, two were stationed in lifeguard chairs (a high chair and a folding chair) at the deep end, and one in a lifeguard chair at the shallow end. At 3:00 P.M., the guard on patrol and a guard stationed at the deep end decided to take a lunch break. The break was unauthorized since it was against policy to leave during open swim. This left one guard in the high lifeguard chair at the deep end and one in a guard chair at the shallow end. The guard in the chair later testified that it was difficult to see due to glare from the sun reflecting off a glass-paneled wall directly behind his chair. At 3:40 P.M., swimmers in the deep end yelled to the guards that someone was at the bottom of the pool. The two guards pulled the boy from the water and began CPR. The pool manager was nearby when he heard a whistle blown by the guard and rushed over to assist with the resuscitation attempts. Several employees were told to call 911 but were unable to get through since they were unaware that they had to dial a "9" first to get an outside line. The paramedics arrived at 4:10 P.M., thirty minutes after the boy was pulled from the water. He was taken to the hospital where he later developed acute bronchial pneumonia and died.

The boy's parents brought suit claiming that the defendant had provided negligent supervision. The city prevailed in the lawsuit in the trial court and again upon appeal. The decisions were based on the applicable statute which provided immunity to a governmental entity where injury or death resulted "from the exercise of judgment or discretion in determining whether to acquire, or how to use, equipment, supplies, materials, personnel, facilities, and other resources unless the judgment or discretion was exercised...in a wanton or reckless manner" R.C.2744.03(A)(5). The court held that the pool management had not acted in a reckless or wanton manner. 
The Supreme Court reversed this decision. The Court held that immunity was not absolute and that reasonable minds could differ as to whether the city acted in a wanton or reckless manner in its use of personnel, facilities and equipment. In particular, the court found it appalling that the city had no policy in place or training regarding the making of 911 calls. The city had admitted they had failed to train their employees in the use of the phone to make 911 calls. Second, the court found that the two lifeguards who left the pool to eat lunch created a dangerous condition by reason of their absence. Testimony revealed the near drowning occurred within five to fifteen feet of the lifeguard chair in the deep end of the pool left empty by the absent lifeguard. Third, the court addressed the issue of glare, which allegedly obstructed the lifeguard's view of the deep end of the pool. The court held that it was for the trier of fact to determine whether the city, which knew about the glare problem at the pool, created an unreasonable risk of harm by not correcting the problem. Given these issues, the Court remanded the case to the trial court for a new trial.

Another case, in which the rescue attempts and the emergency procedures of the lifeguards were questionable, is Johnson v. Washington County (1994). A wrongful death action was brought against the school district and county by the father of a child who, while on a school field trip, drowned in a swimming pool built and maintained by the county. The field trip was planned and supervised by four school district extended day program employees. Only one of them knew how to swim, and she had no training in water safety. The staff rules required the supervisors to enter the water, to count the children at safety breaks, and to alert and help the lifeguards if a child was in danger. The supervisors also had swimming rules for the children, including the requirement to stay with a "buddy", which were read to them several times. The supervisors did not test the swimming ability of the children, but instead relied on the children's own estimate of their ability.

The pool at issue was an artificially created swimming pond with a sand beach and bottom. The bottom sloped gradually with no sudden drop-offs. The water was murky, had no depth markers, nor ropes that divided the areas for swimmers and for nonswimmers. On the day of the accident, five lifeguards were on duty and about 300 people were at the pool.

During a safety break, after the supervisors counted the children, they discovered the decedent was missing. The head lifeguard, passing by, overheard the conversation and asked for a description of the missing child and where he was last seen. A child pointed towards the water. The head guard informed the other guards of the missing child. One guard phoned for emergency assistance, while other people searched the playground, bathroom, and parking lot. Initially, no one searched the water. Only after it was announced over the PA system that the missing child should report to the lifeguard stand was an attempt made to search the water. An attempt was made to form a human chain to search the water, but only fragmented chains were formed. Later, the head guard returned to the swimming area and organized one long chain. On the first sweep through the pond, the child's body was found in about four feet of water.

The jury found that the negligence of the school district and county caused the child's death. The court apportioned 40 percent of the liability to the district and 60 percent to the county, and awarded damages of over one million dollars. The court of appeals affirmed the verdict as to the school district, but reversed as to the county, holding the county immune from liability. The Supreme Court of Minnesota affirmed the decision of the court of appeals.

The case of Johnson v. Y. M. C. A. of Great Falls (1982) also focused on the emergency procedures of the lifeguard staff. A six-year-old boy, enrolled in the "Summer Action Club" sponsored by the Y.M.C.A., was found submerged in about four and one-half feet of water. Resuscitation 
efforts took place and the boy was taken to the hospital where he stayed for four days. The youngster suffered brain damage from the near drowning incident.

The plaintiff filed a complaint alleging that the defendant was negligent in the care and supervision of the boy. The defendant denied the allegations and contended that they had exercised ordinary care in supervising and assisting the plaintiff when he became endangered. The trial court entered judgment in favor of the defendant. On appeal, there was a factual question of whether the defendant had provided a sufficient ratio of lifeguards to pool users. There was also a factual question, raised by the complaint and an expert's testimony, as to how long the boy was under the water. This was the key element of the plaintiff's case. Additionally, there was a factual question of whether the defendant had properly instructed its patrons in pool use in accordance with accepted water safety standards. The appellate court held, by virtue of these and other factual questions that the trial court did not err in failing to grant plaintiff's motion for summary judgment. The decision of the lower court was affirmed.

The knowledge and skill level possessed by all lifeguards must be assessed periodically, regardless of the level and type of certification held. Emergency rescue techniques and practices must be updated to reflect changes in currently accepted procedures. These skills must also be practiced regularly to keep them from deteriorating. The use of certain rescue techniques has been an issue in several lawsuits.

The resuscitative efforts and the use of a spinal board by the lifeguard were at issue in Webber v. Yeo (1986). A wrongful death action was brought by the father of a student who drowned in a school swimming class. The central issue raised on appeal was whether the alleged acts or omissions of the class instructors and school administrators were discretionary or ministerial. The trial court concluded that each of the defendants were shielded by governmental immunity because their actions were discretionary in nature as opposed to ministerial. The plaintiff alleged that the class instructors negligently failed to give the decedent mouth-tomouth resuscitation before removing him from the water, and failed to place him on a spine board while in the water. The appellate court stated that the class instructors exercised personal judgment in determining that resuscitation efforts would be more effective by first removing the decedent from the water, rather than attempting resuscitation of the boy in the deep water of the pool. They concluded that the manner in which the boy was rescued constituted a discretionary act for which the class instructors were shielded with immunity. The plaintiff also alleged that the class instructors failed to properly administer mouth-to-mouth resuscitation and cardiopulmonary resuscitation procedures after removing the boy from the water. The court concluded that these acts were ministerial, and therefore, the class instructors were not protected with immunity for these acts. The appellate court concluded that the trial court properly granted summary judgment with respect to the discretionary acts of the class instructors. However, the court stated that the trial court improperly granted summary judgment as to the ministerial acts of the instructors. The decision, therefore, was affirmed in part and reversed in part.

In regards to the allegation that the lifeguards were inattentive, the court noted that there was evidence that the guards were attentive and watchful. There was evidence that the deceased acted in such a way that his actions should have caused alarm and been noticed. While rejecting the contention that the lifeguards should have immediately used "mouth-to-mouth" respiration, the trial court, while conceding that time is critical in lifesaving, and that there was evidence that the "mouth-to-mouth" approach was the preferred technique, noted that there was also evidence that the techniques first applied were standard and acceptable methods. The findings of the court, which ruled in favor of the city, were 
affirmed.

A swimming pool operator's failure to provide proper instruction and staff training may result in liability. A swimming pool operator must also provide their lifeguard staff with instruction and training in the proper use of safety equipment such as backboards, first aid supplies, oxygen delivery devices, communication equipment, and water rescue equipment, such as paddleboards and rescue tubes. The appropriateness of rescue and/or first aid procedures are issues in several cases. Additionally, several cases illustrate the need for well-rehearsed emergency plans. The Carter and Johnson cases are tragic examples of this point.

All swimming pool employees must know what is expected of them in the event of an emergency. Simulated emergencies, also known as mock rescues, bring a sense of reality to emergency action plan practice. If the staff is accustomed to dealing with mock emergencies in practice, they may be better able to deal with actual emergencies. Documentation of emergency action plan training and practice should be carefully retained. Emergency action plans should also meet the expectations of a facility's legal counsel.

Developing emergency policies and procedures should rank high on the priority list of all swimming pool operators. Serious emergencies may occur very infrequently at some facilities. However, if an emergency does occur, being prepared may mean the difference between life and death, and the difference between a satisfied patron and a lawsuit.

\section{Locker Room Supervision}

In addition to the swimming pool and deck area, swimming pool operators have a duty to provide adequate security and supervision to the remainder of the facility, particularly when children are present. Failure to do so may constitute negligence. The following case provides an example.

In S.W. and J.W. v. Spring Lake Park District No.16 (1999), a fifteen-year-old girl was raped in a girl's locker room adjacent to a school complex swimming pool. She was at the pool to take a swimming test. After the swimming test, she went to the locker room to take a shower and change clothes. It was at this time that she was sexually assaulted. The predator was later caught and convicted of first-degree sexual assault and kidnapping. Prior to the incident, the school secretary, a janitor and the assistant pool director all saw the man as he exited the girl's locker room. He was neatly dressed and carried what appeared to be flower boxes. They did little in response to the man's presence given their belief that he was on the premises for a harmless purpose and that he had merely lost his way and ended up passing through the girl's locker room by mistake. The school district had no security policy in place. Additionally, the employees had no official guidance in how to deal with non-students who were on the premises.

The parent's sued claiming the school district was negligent in failing to provide adequate supervision, protection and security. The employees were not sued individually. The court held that the attack upon the girl was foreseeable since three employees were aware the attacker had been in the girl's locker room and understood that he was not a student and did not belong on the school premises. Foreseeability, reasoned the court, requires actual knowledge of a dangerous condition which imposes a special duty to do something about that condition. The court held that defendant breached its duty to the girl and was not entitled to governmental immunity.

Swimming pool operators must provide some means of security and supervision for all areas of the facility, particularly when children are present. As seen in Spring Lake, unauthorized persons must be prevented from entering locker rooms or other sensitive areas. Failure to do so may constitute liability. Likewise, reasonable security precautions must be made to discourage and prevent unauthorized use of the facility during and after operating hours. 


\section{Summary}

The operator of a public swimming pool extends an open invitation to the public to use his or her facility. In doing so, the operator is bound to use reasonable care for the protection of his or her patrons against reasonably foreseeable dangers. Patrons are entitled to expect that reasonable care has been used to make the premises safe for their use.

As a result of the rapid growth of swimming facilities and the interest in water-based recreation, fitness and rehabilitation, swimming pool operators are much more likely today than ever before to become involved in litigation. In aquatic programs, it is impossible to completely eliminate the risk of injury and death. However, it is possible to minimize that risk. In today's litigious society, it has become imperative for swimming pool operators to implement risk management measures to reduce or eliminate the risk of drownings, near drownings, spinal cord and other injuries.

There are many ways to limit costly lawsuits. Today's aquatic professionals must take it upon themselves to be well informed of the legal aspects of the profession. Legal precedents and duties applicable to the standard of care in swimming pool operation, which are identified by court decisions, could be utilized by swimming pool operators and aquatic professionals in an effort to reduce injuries and deaths, and their exposure to liability. Becoming familiar with relevant court decisions and their implications for aquatic management, along with proper supervision and sound risk management, will reduce the number of injuries, deaths, and subsequent lawsuits, making swimming pools safer and more enjoyable places to play, exercise and work.

\section{References}

American Red Cross. (1992). Swimming and diving. Saint Louis, MO: Mosby Lifeline.

American Red Cross. (1995). Community water safety. Saint Louis, MO: Mosby Lifeline.

Baley, J. A., \& Matthews, D. L. (1989). Law and liability in athletics, physical education, and recre- ation. Dubuque, IA: Willam C. Brown.

Clement, A. (1997). Legal responsibility in aquatics. Aurora, $\mathrm{OH}$ : Sport and Law Press.

DeVivo, M. J. \& Sekar, P. (1997). Prevention of spinal cord injuries that occur in swimming pools. Spinal Cord, 35, 509-515.

Edelstein, M. (1999). Losing the competitive edge? Aquatics International, 11, 26.

Fields, A. I. (1992). Near drowning in the pediatric population. Critical Care Clinics, 8, 113-129.

Gabriel, J. L. (1988). Diving safety: A position paper. Indianapolis, IN: United States Diving.

Gabriel, J. L. (1992). Diving safety: A position paper (2nd ed.). Indianapolis, IN: United States Diving.

Gabrielsen, M. A. (Ed.). (1987). Swimming pools, a guide to their planning, design, and operation (4th ed.). Champaign, IL: Human Kinetics.

Gabrielsen, M. A., \& Olenn, J. R. (1982). Swimming pool litigation: Educating for safety. Trial, $18,38-41$.

Gabrielsen, M. A., \& Spivey, M. (1990). The etiology of 486 case studies with recommendations for needed action. Fort Lauderdale, FL: Nova University Press.

Holford, E. J. (1987). Swimming pool supervision: Lifeguards as linchpins in avoiding liability. Sports, Parks, and Recreation Law Reporter, 1, 5-7.

Hoyert, D. L., Kochanek, K. D., \& Murphy, S. L. (1999). Deaths, death rates, and age-adjusted death rates for injury deaths according to mechanism and intent of death: United States, 1997. National Vital Statistics Reports, 47 (19). Atlanta, GA: Centers for Disease Control and Prevention.

Johnston, K. M., \& Bruya, L. D. (1999). A tool to reduce risks. Aquatics International, 11, 18-19.

National Spa and Pool Institute. (1994). Pool and spa market study for the year 1993. Alexander, VA: National Spa and Pool Institute.

National Safe Kids. (1999). Drowning fact sheet. Retrieved October 14, 1999 from the World Wide Web: http://www.safekids.org/fact99/drown99.html

Osinski, A. (1990). The complete aquatic guide. Parks and Recreation, 25, 36-43.

Reagan, M. J., \& Gabrielsen, M. A. (1990). Diving tragedies: still water doesn't run deep. Trial, 26, 98-102.

Sobo, G. (1998). Look before you leap: can the 
emergence of the open and obvious danger defense save diving from troubled waters? Syracuse Law Review, 49. Retrieved November 2, 1999 from the World Wide Web: http://www.lexis-nexis.com/universe/doc

Sporting Goods Manufacturers Association. (1999). America's top 25 participation sports according to new Superstudy statistics. Retrieved October 25, 1999 from the World Wide Web: http://www. sportlink.com/press_room/1999_releases/m99. 018.html

Thanel, F. (1998). Near drowning: Rescuing patients through education as well as treatment. Post Graduate Medicine, 103, 144-153.

Wintemute, G. J. (1990). Childhood drowning and near drowning in the United States. American Journal of Diseases of Children, 144, 663-669.

\section{Table of Cases}

Ald v. Cunningham, 184 N.W.2d 360 (Mich. App. 1970).

Andrews v. Taylor, 239 S.E 2d 630 (N.C. App. 1977).

Barnett v. Zion Park District, 171 Ill.2d 378; 665 N.E.2d 808 (Ill. 1996).

Cassio v. Creighton University, 446 N.W.2d 704 (Neb. 1989).

Cater, et al v. City of Cleveland, 83 Ohio St.3d 24; 697 N.E.2d 610 (Ohio 1998).

Corda v. Brook Valley Enterprises Inc., 306 S.E 2d 173 (N.C. App. 1983).

Dartez v. Gadbois, 541 S.W.2d 502 (Tex. App. 1 Dist. 1976).

Ely v. Northumberland General Insurance Co., 378
So.2d 1024 (La. App. 2 Cir. 1979).

Honeycutt v. City of Monroe, 253 So.2d 597 (La. App. 2 Cir. 1971).

Jeffords v. Atlanta Presbytery Inc., 231 S.E.2d 355 (Ga. App. 1976).

Johnson v. City of Darlington, 466 N.W. 2d 233

(Wisc. App. 1991).

Johnson v. Washington County, 518 N.W.2d 594

(Minn. 1994).

Johnson v. YMCA of Great Falls, 651 P.2d 1245 (Mont. 1982).

Manganello v. Permastone, Inc., 231 S.E.2d 678 (N.C. 1977).

Mullery v. Ro-Mill Construction Corp., 429 N.Y.S.2d 200 (1980).

Phillips v. Southeast 4-H Educational Center, Inc., et al, 257 Va. 209; 510 S.E.2d 458 (Va. 1999).

$S \& C$ Company v. Horne, 235 S.E.2d 456 (Va. 1977).

Shields v. Watervliet, 341 N.Y.S.2d 699 (A.D. 2 Dept. 1973).

Smith v. Village of Pine River, 232 N.W.2d 241 (Minn. 1975).

Stillwell v. City of Louisville, 455 S.W.2d 56 (Ky. App. 1970).

S.W. and J.W. v. Spring Lake Park District No.16, 580 N.W.2d 19 (Minn. 1998).

Turner v. Parish of Jefferson, Houma Motels, et al, 721 So.2d 64 (La. App. 5 Cir.1998).

Robinson v. City of Decatur, 325 S.E.2d 752 (Ga. 1985).

Webber v.Yeo, 383 N.W.2d 230 (Mich. App. 1985). Williams v. United States, 660 F.Supp. 699 (E.D. Ark. 1987).

\section{The Society for the Study of the Legal Aspects of Sport \& Physical Activity}

Thomas H. Sawyer, Ed.D., Executive Director

5840 South Ernest Street, Terre Haute, IN 47802 pmsawyr@aol.com

Make check payable to: SSLASPA

Name

Institution/Organization

Address

Phone (office)

Fax

E-mail:

$\square$ Professional $\$ 50 \quad \square$ Student $\$ 30$ 